\title{
Expected Qualities of Literature Graduates in the Perception of Vietnamese School Teachers
}

\author{
Nguyen Thi Hao \\ University of Social Sciences and Humanities \\ Vietnam National University Ho Chi Minh City, Vietnam \\ E-mail: haonguyenpy2@hcmussh.edu.com \\ Tran Thanh Huong (Corresponding author) \\ University of Social Sciences and Humanities \\ Vietnam National University Ho Chi Minh City, Vietnam \\ E-mail: tranthanhhuong@hcmussh.edu.vn
}

Received: December 3, 2018 Accepted: December 25, 2018 Published: December 26, 2018

doi:10.5296/gjes.v4i2.13993 URL: https://doi.org/10.5296/gjes.v4i2.13993

\begin{abstract}
This study aims to examine the expected qualities of teacher graduates from literature preparation programs, and the importance of these qualities to the classroom practice, according to the perceptions of school teachers. Two hundred eighteen (218) participants were conveniently selected from various schools in Ho Chi Minh City. Literature graduates from teacher preparation programs in 2017 are the subject to be reported by these participants. A 78-item researchers-constructed questionnaire was distributed by google form and hard copy. This questionnaire asked participants about the expected qualities of literature graduates and its importance to teaching practice in related to teacher graduates' knowledge, instructional strategies, personal characteristics, and professional development. Results indicated that, there are 60 required qualities from literature graduates and all are perceived as "important" to school practice. Implications are drawn from the findings for teacher education and for further researchers.
\end{abstract}

Keywords: Teacher's quality, Teacher graduates, Literature teacher, Teacher preparation program 


\section{Introduction}

The development of technology and international integration has changed to all the aspects of human life. The transition from industry 3.0 to the era of industry 4.0 with the emphasis of knowledge has challenged to all education system in shaping the human resource with relevant capability and competence to compete in the competitive world (OECD, 2001; Yelland, 2006) rather than achieving high level of education alone. This context has brought to the reform in all the aspects of education in many countries around the world and Vietnam is none of this exception.

In order to prepare competent students for increased demands of knowledge-based economy and skilled labor for national development, Vietnam government has issued the resolution No 29-NQ/TW (2013) to innovate basic and comprehensive education, and following by the resolution 88/2014/QH13 and 404/QD-TTg which have targeted to renovate general education curriculum for better quality. Although lots of remarkable achievements have been reached at national and international levels, various weaknesses have been criticized (Mai \& Yang, 2013; OECD, 2013; Lan, 2017; Nhat, 2018) in term of teaching quality, student's performance, and their competence. To address this issue, the new general education curriculum framework has approved in 2017 and will be pilot implemented in 2019 with its aims to develop students' the key qualities and competencies of 21 st century citizens.

With the aims of new curriculum, teacher professionalism and their quality become one of the top most concerns (Stronge, 2013; Ko et al., 2016) because their role is essential and their competence are crucial to education reforms and school success (Prime Minister Nguyen Xuan Phuc, 2018). Concerns about the quality of nation's education and in consideration of teachers' professional competency, the Ministry of Education in Vietnam has issued the teacher professional standards framework in August, 2018 which is seen as guideline for teacher preparation, teacher's professional development and teacher's evaluation (Circular No 20/2018/TT-BGDĐT). This framework has generally defined the required knowledge, skills and personal attributes of qualified teachers as follow: teachers need to have professional ethics with appropriate attitudes toward their task such as creating educated environment with cultural-based and autonomous-based atmosphere, provide safety learning environment. Teachers are also asked to develop interrelationship and collaboration with different stakeholders to help student learning. In addition, teachers have to continuously develop their profession in term of content knowledge and pedagogical skills (competency-based approach). The framework also requires teachers' ability to use foreign languages/ ethnic language and apply technology into teaching. These requirements have emphasized on the responsibility of teacher preparation program in training quality teacher candidates who have to meet these standards.

The quality of teachers reflects school quality and influences students learning outcomes (Adoniou, 2013, Coe et al., 2014; Ko et al., 2016; Stronge, 2018). Thus, the quality of teacher candidates is very important to every education system; Coggshall et al. (2012) stated that understanding the quality of teacher candidates will be one of the predictors of student achievement and teacher's effectiveness in the classroom. Teaching isn't for poor-prepared 
teachers (Stronge, 2013), the quality of teachers, especially the quality of teacher graduates will determine the level of knowledge and skills they bring to the classroom. Past studies had indicated the complexity of classroom practice with the uniqueness of each school settings and the diversity of learners, for this reason, understanding the expected quality from teacher graduates is an important step to prepare qualified teacher and effective teacher for the reality of classroom practice.

Practically, the term quality is usually perceived as "good" or "valuable", the quality teacher is understood as "effective" one in classroom or the one who satisfies stakeholders' needs. There is a complex definition about the quality of effective teachers, Kusmic (1994) stated quality teacher is "carefully consider the content of what taught to children, are active in developing original curriculum based on their own or their pupils' interests, are able to use materials creatively, personal talents and innovative resources in planning and implementing learning activities." (cited by Adoniou, 2013). In other words, McConney et al. (2012) defined the quality of teachers consists of their ability to develop students cognitive while providing emotional and social support. The needed quality of teachers consists of teacher qualifications, teacher characteristics, teacher instruction (practices), and teacher effectiveness (Goe \& Stickler, 2008). Ida (2017) concluded that personal traits and professional competencies are required qualities of effective teachers. The required quality of teacher is diverse and it must be trained during teacher preparation process (Ko et al., 2016). Although the details of quality teacher are perceived differently, the quality of an effective teacher relates to the quality of teacher knowledge, skills, and professional characteristics.

Regarding to the quality of teachers, Coe et al. (2014) claimed that the features to make effective teachers include: deep content knowledge and knowledge of materials/ method to be taught to students, high quality in giving instruction which is specific and practical, create supportive classroom climate and positive interaction, rich classroom management skills, having professional behaviors to develop professional practice, supporting colleagues, and communicating with parents. In light of this discussion, Ida (2017) pointed out that among the required qualities of (a) teachers' content knowledge, (b) planning pedagogical processes and activities, (c) develop students' personality, (d) develop students' sense of community, (e) continuously analyze and assess pedagogical processes, (f) professional communication and cooperation, (g) professional commitment and responsibility, the factors of supporting students' learning is the most significant competence of an effective and quality teacher.

In another point of view, Ko et al. (2016) explained that the characteristics of effective teacher are shown by the clearness of their instructional goals, clear communication, smartly use of existing instructional materials, provide appropriate feedback to help students improve their learning, have knowledge of curriculum and teaching strategies, understand students and their needs, develop students' meta-cognitive strategies and address students' level of cognitive objectives, integrate instruction with other subject as well as responsibly accept student outcomes. According to authors, teachers' behavior, which is presented through their emotional support (such as create positive classroom climate, sensitivity and pay their regards to students), classroom organization (with effective behavior management, productivity, and instructional learning formats), and instructional supports, is an important factor influencing 
student achievement. With the same interest in getting to know the required quality of teacher in the classroom, Katherine et al. (2016) have conducted the survey on students and other stakeholders, results showed that establish good relationship, make ideas clear, show teacher's patience and caring to students, and have deep subject knowledge are perceived as the five most important qualities of good teachers in Vietnam context.

Stronge (2018) further emphasized that successful teaching involves careful preparation because practical teaching not only requires for teacher's quality in term of skills and content knowledge but also the whole person of teachers. While the domain of knowledge and skills involves to subject matters as well as strategies in teaching (learning environment, instructional delivery, learning environment), the whole person of teachers concern to their unique beliefs, values, attitudes, their aspiration and motivation. Because of the complex teaching profession and its required competencies, according to author, the practice-based approach should be applied in pre-service teacher training, so that teachers will be well-prepared to achieve at desirable levels when they walk through the school zone door.

The quality of teachers has become crucial in all school settings especially to student achievement; Schleicher (2012) defined the required qualities of teachers in the 21st century as follow: having deep content knowledge and flexible use of different methods, know how to use different approaches in teaching, have ability to use various teaching strategies at particular settings, use diverse instruction to facilitate students' experience and improvement, have deep understanding about students and their uniqueness, ability to collaborate with different stakeholders, and using technologies and learning from experience through reflecting on teaching practices. In addition, teacher's ability to use differentiated pedagogical practices also is an important quality of teacher in present context, especially in facing the diversity of classroom practices.

Effective teaching requires for wide range qualities of teachers, previous studies have discussed about the standards of being a teacher and required qualities of an effective one. Although many evidences have proven the countless qualities of teachers nowadays, there is little information about the expected quality of teacher candidates and their ability to demonstrate effective teaching in actual practices after completing a teacher preparation program (Coggshall et al., 2012). Actually, it was noticed that many graduates from teacher preparation programs are unprepared and unable to deal with complex classroom practice due to the lack of classroom-ready skills and experiences (Adonious, 2013; McLeskey \& Brownel, 2015; Green et al., 2018). In other words, many of them are trained and their acquisition doesn't match with classroom requirements. Adoniou (2013) emphasized that producing quality teachers is a continuously process, it involves to the cooperation among the employer, the university, the practicum, and the teachers themselves. While university is accountable for the quality of teachers being produced, the usefulness and effectiveness of these qualities will be evaluated by school's stakeholders, therefore, the feedback from these stakeholders is very significant for teacher preparation programs to improve its training quality as well as to produce qualified teachers for the reality of school needs.

Traditionally, Vietnam government regulates teachers quality focuses on qualification with 
certification requirement. It means all teachers are required to take training with certain qualities through university based examination before going to teach. Though certification can qualify teachers to enter the teaching profession, it doesn't mean that all of graduates meet the demands of teaching practice (Pham, 2016; Tu \& Hanh, 2017; Minh, 2017) and positively respond to school needs. It rises to the concern regarding what specific quality is needed for teacher graduates and how important of these qualities to teaching practice at particular schools, especially in the context of wide-range reform in all the aspects of Vietnam education. For this reason, this study was conducted to examine 1) what qualities are literature teacher candidates expected to possess in Vietnam present classroom context? 2) How important are these qualities in the classroom practice? 3) What implication of the findings can be drawn from the findings? Results from this investigation will provide significant information to authorities in preparing teacher candidates who are expected to be effective and responsive in the classroom. Furthermore, results from this study also serves as initially sources for authors to develop literature teacher competency framework though this matter is not new in other educational systems.

\section{Methodology}

\subsection{Respondents of the Study}

The aim of this study was to determine the expected qualities of literature teacher graduates and its importance to teaching practice in the perception of teacher educators and school teachers. To achieve this aim, the 218 primary participants were conveniently selected at four universities where offer teacher education program, and high school teachers in Ho Chi Minh City. Specifically, they are literature lecturers at the universities, and the principals, head teachers and teachers at high schools. Graduates from literature teacher preparation programs in 2017 are the subject to be reported by these participants.

\subsection{Data Collection}

A questionnaire was developed in the reference of Vietnam general education objectives, the teacher standard framework, and related literatures and studies. The questionnaire was constructed into two parts; the first aims to get participant's demographic profiles include gender, age and number of year in the service, working position, and working place. The second part investigates the expected qualities of literature teacher candidates and its importance to teaching practice which is categorized into four domains, (1) content and pedagogical knowledge, (2) instructional strategies (focus on pedagogical skills and nourishing learning environment), (3) professional characteristics which concerns on teacher's ethics toward students, and stakeholders, (4) and teacher's professional development.

After connecting to school administrators and getting their approval to conduct the research, hard copy and google form of the questionnaire with 78 items were sent to these locations to gather data. The respondents were asked to select expected qualities of literature teacher graduates from the list of 78 items questionnaire. After being checked for its relevance and applicability, 18 items were removed by the respondents, and therefore, the remained 60 
items was treated as expected qualities of literature graduates.

The importance of each quality in the reality of teaching practice is interpreted by the mean score. The five point type are used to rate the items according to its importance they personally thought teacher graduates have to achieve in order to be effective in teaching. The SPSS is used as statistical technique to treat data, the meaning is interpreted by the mean score as follow: level 1 with the mean score 1-1.80: Not important; level 2 (M: 1.81-2.60): Slightly important, and graduates need to have understanding about this item and must acquire it; level 3 (M: 2.61-3.40): Moderately important, teacher graduates need to have ability to do the mentioned matter with someone' guidance at particular situation; level 4 (M: 3.41-4.20): Important and teacher graduates have ability to do this item independently in the complex practice; level 5 (Mean: 4.21-5): Very important, so graduates need to achieve high level of proficiency to be able to train others.

\section{Results and Discussion}

\subsection{Demographic Profile of the Respondents}

Table 1. Demographic profile

\begin{tabular}{|c|c|c|c|c|c|c|c|c|}
\hline \multicolumn{2}{|c|}{ Gender } & \multicolumn{2}{|l|}{ Age } & \multicolumn{2}{|l|}{ Position } & \multicolumn{2}{|c|}{ Place of work } & \multirow{2}{*}{$\begin{array}{l}\text { Num of } \\
\text { year in } \\
\text { service }\end{array}$} \\
\hline Male & Female & & $\begin{array}{c}\text { Teaching } \\
\text { staff }\end{array}$ & $\begin{array}{c}\text { Teachers with } \\
\text { administrative task }\end{array}$ & Administrator & $\begin{array}{l}\text { High } \\
\text { school }\end{array}$ & University & \\
\hline 31.1 & 68.9 & 42.4 & 70.6 & 15.0 & 14.4 & 86.2 & 13.8 & 16.84 \\
\hline
\end{tabular}

Table 1 shows that there are more female respondents (68.9) than male (31.1\%), and most of them carry a task as teaching staff $(70.6 \%)$ rather than administrative task (14.4\%), others also take both two duties, teaching and administration and they usually are department head (15.0\%). Although their average age is 42.41 , the average year to involve in school service of the respondents is not as many as their age (average age in the service is 16.84 years only). It means that before taking permanent job at present school, they already had experience in other places. Data also indicates that most of the respondents are working at schools $(86.2 \%)$ while other percentage is working at universities (13.8\%).

Table 2. Educational attainment of the respondents

\begin{tabular}{lc}
\hline Educational attainment & Percentage \\
\hline Bachelor & 69.0 \\
Master & 23.0 \\
Ph.D & 6.1 \\
Others & 1.9 \\
Total & $\mathbf{1 0 0}$ \\
\hline
\end{tabular}




\section{MInstitute ${ }^{\text {Mnk }}$}

Global Journal of Educational Studies

ISSN 2377-3936

2018, Vol. 4, No. 2

While bachelor holders is a majority group (69\%), the Ph.D holders occupies for the smaller percentage with $6.1 \%$, and the rest places on the masteral degree holders with $23 \%$. Data also shows that there is 1.9 percent of teachers who have not met the present Vietnam teacher standards yet (all high school teachers are required to achieve at least bachelor degree, and masteral degree for teachers at higher education), other $23 \%$ places on masteral degree holders. It reflects that most of them are qualified to teach at appropriate level though other small percentage needs to be trained to reach required teaching standards.

\subsection{Expected Qualities of Literature Teacher Graduates}

The expected qualities of literature candidates and its importance to teaching practice is perceived as follow:

\subsubsection{Content Knowledge and Pedagogical Knowledge}

\begin{tabular}{|c|c|c|c|}
\hline No & The quality of knowledge & Mean & SD \\
\hline 1 & $\begin{array}{l}\text { Linguistic proficiency (both in reading, writing, speaking, and } \\
\text { listening). }\end{array}$ & 3.86 & 0.78 \\
\hline 2 & $\begin{array}{l}\text { Using multimedia sources to interpret and convey the content of the } \\
\text { subject. }\end{array}$ & 3.67 & 0.86 \\
\hline 3 & $\begin{array}{l}\text { Establish links between language and students' needs outside } \\
\text { classroom. }\end{array}$ & 3.62 & 0.87 \\
\hline 4 & Employ theories and research findings into subject teaching. & 3.57 & 0.88 \\
\hline 5 & $\begin{array}{l}\text { Overarching conceptions of literature subject and design teaching } \\
\text { activities that meet teaching and learning objectives. }\end{array}$ & 3.53 & 0.87 \\
\hline 6 & $\begin{array}{l}\text { Selecting and using relevant instructional materials to deliver the } \\
\text { content clearly and correctly. }\end{array}$ & 3.56 & 0.81 \\
\hline 7 & Using information technology to managing student's learning. & 3.57 & 0.85 \\
\hline 8 & $\begin{array}{l}\text { Identify the faced challenges in teaching practice and have coping } \\
\text { mechanism. }\end{array}$ & 3.53 & 0.86 \\
\hline 9 & Have knowledge of how to teach literature to student in details. & 3.61 & 0.79 \\
\hline 10 & Using various assessment forms to evaluate student's learning. & 3.60 & 0.81 \\
\hline \multirow[t]{2}{*}{11} & $\begin{array}{l}\text { Using information technology to manage and communicate with } \\
\text { stakeholders regarding students learning. }\end{array}$ & 3.60 & 0.83 \\
\hline & Overall mean & 3.61 & \\
\hline
\end{tabular}

It is repeated that the Vietnam new curriculum focused on promoting students' cognitive and behavioral skills to gain employment and emerge into national economic growth, therefore, today teaching requires for teachers' high-level competence to support and inspire student learning. In literature subject, students will no longer learn given essays by rote, but they are encouraged to express their own viewpoints and giving creative ideas. To achieve this objective, teachers must have broad pedagogical knowledge and deep understanding about the taught subject with its methodology and resources/ materials to facilitate learning process and foster student's creative thinking. In the perception of the respondents, deep content 
knowledge and knowledge of pedagogy in teaching literature are both important to teacher graduates $(\mathrm{M}=3.61)$. It means literature graduates are expected to have knowledge about literature principles, techniques and teaching materials in order to teach, to manage and to inspire students independently and effectively. This result is similar to the findings of Schleicher (2012), Guerriero (2013), and Coe et al. (2014) who also considered content knowledge is as imperative indicators of an effective teacher.

\subsubsection{Expected Qualities of Literature Graduates in Related to Instructional Strategies}

\begin{tabular}{|c|c|c|c|}
\hline No & The quality of instructional strategies & Mean & SD \\
\hline 1 & $\begin{array}{l}\text { Identifying students' personal needs and ability to adapt appropriate } \\
\text { instruction. }\end{array}$ & 3.46 & 0.82 \\
\hline 2 & Update latest research findings into subject teaching. & 3.41 & 1.08 \\
\hline 3 & Adapt appropriate instruction to students' cognitive levels. & 3.54 & 0.87 \\
\hline 4 & Select teaching strategy that fits with student's uniqueness. & 3.54 & 0.99 \\
\hline 5 & $\begin{array}{l}\text { Design lesson plan based on scientific evidence from both national and } \\
\text { international research findings. }\end{array}$ & 3.57 & 0.88 \\
\hline 6 & $\begin{array}{l}\text { Applying various teaching strategies to holistically develop students' } \\
\text { linguistic competence. }\end{array}$ & 3.59 & 0.79 \\
\hline 7 & $\begin{array}{l}\text { Employing various teaching strategies to develop student's linguistic } \\
\text { competence in integration with other subject areas. }\end{array}$ & 3.45 & 0.92 \\
\hline 8 & Focus on the development of students core competencies. & 3.49 & 0.85 \\
\hline 9 & $\begin{array}{l}\text { Design teaching activities that engage students with other cultures, and } \\
\text { aware of themselves as globalized citizens. }\end{array}$ & 3.23 & 0.96 \\
\hline 10 & $\begin{array}{l}\text { Facilitate learning with adequate classroom arrangement that fits with } \\
\text { teaching activities. }\end{array}$ & 3.56 & 0.81 \\
\hline 11 & Using technological resources to enhance students' learning. & 3.54 & 0.82 \\
\hline 12 & $\begin{array}{l}\text { Provide different opportunities to engage students into community } \\
\text { activities. }\end{array}$ & 3.42 & 0.96 \\
\hline 13 & Applying information technology to monitor student's learning. & 3.60 & 0.83 \\
\hline 14 & Effectively monitor classroom activities. & 3.53 & 0.99 \\
\hline 15 & Using variety of instruction to motivate students' learning. & 3.61 & 0.85 \\
\hline \multirow[t]{2}{*}{16} & $\begin{array}{l}\text { Designing regular and appropriate assessment techniques to monitor } \\
\text { students' improvement. }\end{array}$ & 3.49 & 0.85 \\
\hline & Overall mean & 3.50 & \\
\hline
\end{tabular}

Instructional strategies are positively associated with student skill acquisition, their performance and attitudes toward learning (Le Donne et al., 2016). For this reason, teachers from school sectors perceived that using different teaching strategies are significant to classroom practice $(\mathrm{M}=3.50)$ and literature graduates have to attain these qualities before going to teaching profession. By using different instructions, students not only are encouraged to engage in learning but also are motivated to develop themselves for better 
achievement. However, in the perception of school teachers, the quality of "design teaching activities that engage students with other cultures, and aware of themselves as globalized citizens" is considered not a strict requirement for literature graduates (item 9 with $\mathrm{M}=3.23$ ) or not so important in the reality of teaching at school sector.

\subsubsection{Expected Professional Characteristics of Literature Graduates}

\begin{tabular}{llcc}
\hline No & The quality of professional characteristics & Mean & SD \\
\hline 1 & $\begin{array}{l}\text { Responsive and proactive to all unpredictable issues in the } \\
\text { classroom. }\end{array}$ & 3.55 & 0.82 \\
2 & Positively respond to student's questions and suggestions. & 3.46 & 0.80 \\
3 & Establish good relationship with colleagues. & 3.25 & 0.84 \\
4 & Establish good relationship with students. & 3.77 & 0.83 \\
5 & Establish good relationship with students' parents/guardians. & 3.51 & 0.94 \\
6 & Providing relevant support and guidance to help students face with & 3.55 & 0.87 \\
& their encountered learning problems. & & \\
7 & Guide and monitor group activities in class. & 3.62 & 0.89 \\
8 & Sensitively recognize and respect student's differences. & 3.54 & 0.97 \\
9 & Keep a positive atmosphere in the classroom. & 3.51 & 0.89 \\
10 & Address student uniqueness respectively and creatively. & 3.57 & 0.89 \\
11 & Fairly evaluate students' learning based on specific rubrics. & 3.57 & 0.79 \\
12 & Inform to students about assessment guideline and rubrics. & 3.65 & 0.80 \\
13 & Encourage students to self-evaluate and evaluate others. & 3.66 & 0.81 \\
14 & Provide positive feedback to improve student learning. & 3.54 & 0.86 \\
15 & Inform and consult parents/ guardians about students' performance. & 3.45 & 0.89 \\
16 & Encourage the involvement of students' family in learning. & 3.42 & 0.89 \\
17 & Actively listening to stakeholders' feedback in order to adjust & 3.52 & 0.89 \\
& teaching. & & \\
18 & Guiding students to look for family supports when needed. & 3.55 & 0.87 \\
19 & Establish good relationship with individuals and organization that & 3.26 & 0.95 \\
& $\begin{array}{l}\text { relates to students' learning. } \\
\text { Overall mean }\end{array}$ & $\mathbf{3 . 5 2}$ & \\
\hline
\end{tabular}

Another expected quality of literature graduates is their professional characteristics. This domain is described by teachers' beliefs and values toward learners and their task. In respondents' perception, this quality is also important to literature graduates who are expected to have professional ethics, belief and morals towards students' differences and their needs $(M=3.52)$. It means that literature graduates are expected to have ability to deal and manage learning activities which bases on trust, caring, sensitivity, equality, respect, informative and clear communication, and empowerment of stakeholders. This result is consistent with Schleicher (2012) and Katherine et al. (2016) findings. Although the domain of teaching strategy with design teaching activities to promote multi-culture is considered as 
moderately important to literature graduates, their behavior towards this aspect is indicated as "important" for the needs of the classroom.

3.2.4 Expected Qualities of Literature Graduate in Professional Development

\begin{tabular}{|c|c|c|c|}
\hline No & The quality of professional development & Mean & SD \\
\hline 1 & $\begin{array}{l}\text { Using foreign language as a mean to learn and to look for opportunity for } \\
\text { professional development. }\end{array}$ & 3.11 & 1.13 \\
\hline 2 & $\begin{array}{l}\text { Continuously self-mastering professional competence and personal } \\
\text { attributes. }\end{array}$ & 3.64 & 0.83 \\
\hline 3 & $\begin{array}{l}\text { Collaborating with colleagues to learn and support students in special } \\
\text { needs. }\end{array}$ & 3.54 & 0.94 \\
\hline 4 & Observing other teachers to improve classroom practice. & 3.56 & 0.89 \\
\hline 5 & $\begin{array}{l}\text { Attending regular meetings to share and to learn the best teaching } \\
\text { practices. }\end{array}$ & 3.72 & 0.79 \\
\hline 6 & Reflect on students' achievement to improve teaching. & 3.63 & 0.79 \\
\hline 7 & $\begin{array}{l}\text { Employing different approaches and techniques to get understand } \\
\text { students' needs. }\end{array}$ & 3.38 & 0.99 \\
\hline 8 & Using available resources to improve teaching. & 3.60 & 0.99 \\
\hline 9 & $\begin{array}{l}\text { Informing learning objectives, activities, and students' outcomes to } \\
\text { parents/ guardians. }\end{array}$ & 3.49 & 0.95 \\
\hline 10 & Getting public feedback to adjust teaching objectives and methodology. & 3.18 & 1.07 \\
\hline 11 & Self-evaluate teaching to have adequate modification. & 3.56 & 0.95 \\
\hline 12 & $\begin{array}{l}\text { Collaborating with various individuals and organizations to develop } \\
\text { students' competencies. }\end{array}$ & 3.25 & 0.98 \\
\hline 13 & Update educational strategies and policies. & 3.41 & 0.93 \\
\hline \multirow[t]{2}{*}{14} & $\begin{array}{l}\text { Employing teaching experiences and students' learning outcomes to } \\
\text { enhance teaching quality. }\end{array}$ & 3.42 & 0.99 \\
\hline & Overall mean & 3.46 & \\
\hline
\end{tabular}

The reform in Vietnam new curriculum frameworks has added mandated new requirements to existing curriculum in term of knowledge acquisition and skill development that imposes on teachers' responsibility. It requires for the changes not only in teachers' academic competency but also their professional development. While professional development is part of teaching profession (Vietnam Education Law, 2015; Circular No 20/2018/TT-BGDĐT), this activity is considered as a mean to upgrade teacher's profession in order to face with all classroom challenges and to meet the diverse demands of students (Schleicher, 2012). For this reason, the respondents perceived that self-learning, communicate and collaborate with others for teaching improvement, using available resources to enhance teacher knowledge and skills, are important and must be acquired by literature graduates $(\mathrm{M}=3.46)$. 


\section{Conclusion}

Researchers have indicated that the quality of teachers has large impact on students' learning (Stronge, 2013; Ko et al., 2016) and it is an essential element for improving students' capacity to compete in globalized economy. The quality in each aspect of literature graduates was selected and examined by school teachers. Findings show that 60 among 78 items are perceived as expected qualities and these are "important" to the reality of school needs.

While competency-based approach is going to apply in Vietnam new curriculum, there is no specific description about the required competency framework for Vietnamese teachers and literature teachers in particular. Although this study conducted on the selected group of respondents in literature subject, all the qualities are chosen by school teachers need to be considered in teacher preparation program structure and program content, so that literature teacher graduates will be well-prepared to teach in new curriculum effectively. In addition, how "good and successful teaching" is perceived by stakeholders, therefore, due to the scope of this study in term of time, location and number of the respondents, there should have further researches regarding to expected quality of teachers from the perspective of students and other stakeholders so that teacher competency framework will be practically constructed in order to direct teacher training and teacher performance in Vietnam.

Findings from this study contributes knowledge to the field of literature teacher preparation program though it is not broad enough to come up with the final conclusion related to the quality of literature teacher, thus, other investigations regarding teacher preparation outcomes, the effectiveness of in-service teachers and their response to school demands also need to be conducted by different research methodologies so that successful learning and effective teaching will be promoted.

\section{Acknowledgement}

This research is funded by Vietnam National University, Ho Chi Minh City (VNU - HCM) under grant number: (C2016-18b-9)/HĐ - KHCN.

\section{References}

Adoniou, M. (2013). Preparing Teachers - The Importance of Connecting Contexts in Teacher Education. Australian Journal of Teacher Education, 38(8), 47-60. https://doi.org/10.14221/ajte.2013v38n8.7

Circular No 20/2018/TT-BGDĐT. (2018). Vietnam Ministry of Education. Retrieved from https://thuvienphapluat.vn/tintuc/vn/thong-bao-van-ban-moi/email/21501/regulations-on-edu cation-coming-into-force-from-the-beginning-of-october-2018

Coe, R., Aloisi, C., Higgins, S., \& Major, M. E. (2013). What makes Great Teaching? Review of the Underpinning Research. Center for Evaluation and Monitoring, Durham University.

Coggshall, G. J., Bivona, L., \& Reschly, J. D. (2012). Evaluating the Effectiveness of Teacher Preparation Programs for Support and Accountability. Research and Policy Brief, National Comprehensive Center for Teacher Quality. 


\section{Al Macrothink}

Global Journal of Educational Studies ISSN 2377-3936 2018, Vol. 4, No. 2

Congress XIII. (2014). Resolution No. 88/2014/QH13: Renovation of textbooks and general education textbooks. Retrieved

from http://en.cand.com.vn/tag/Resolution-88-2014-QH13-135323

Decision No. 404/QD-TTg. (2015). The Scheme on renewal of general education textbooks and programs. Retrieved from https://thuvienphapluat.vn/van-ban/Giao-duc/Quyet-dinh-404-QD-TTg-2015-doi-moi-chuong -trinh-sach-giao-khoa-giao-duc-pho-thong-270720.aspx

Green, C., Eady, M., \& Andersen, P. (2018). Preparing Quality Teachers. Teaching \& Learning Inquiry, 6(1). https://doi.org/10.20343/teachlearninqu.6.1.10

Guerriero, S. (2013). 'Teachers' Pedagogical Knowledge and the Teaching Profession. OECD. Retrieved from http://www.oecd.org/education/ceri/Background_document_to_Symposium_ITEL-FINAL.pd $\mathrm{f}$

Ida, S. Z. (2017). What Makes a Good Teacher? Universal Journal of Educational Research, 5(1), 141-147. https://doi.org/10.13189/ujer.2017.050118

Katherine, M., Lacey, G., Jessica, Y., \& John, G. (2016). Vietnam: What makes an Effective Teacher. Pearson Education

Ko, J., Sammons, P., \& Bakkum, L. (2016). Effective Teaching. Education Development Trust. University of Oxford.

Lan, H. (2017). Accountability in Vietnam's Education: Toward Effective Mechanism in the Decentralization Context. Global Education Monitoring Report. UNESCO.

Le Donné, N., Fraser, P., \& Bousquet, G. (2016). Teaching Strategies for Instructional Quality: Insights from the TALISPISA Link Data. OECD Education Working Papers, No. 148, OECD Publishing, Paris. https://doi.org/10.1787/5jln1hlsr0lr-en

McConney, A., Price, A., \& Woods-McConney, A. (2012). Fast Track Teacher Education: A Review of the Research Literature on Teach For All Schemes. Perth, WA: Murdoch University Centre for Learning, Change and Development. Retrieved from https://files.eric.ed.gov/fulltext/ED529919.pdf

McLeskey, J., \& Brownell, M. (2015). High-leverage practices and teacher preparation in special education (Document No. PR-1). University of Florida, Collaboration for Effective Educator, Development, Accountability, and Reform Center

Minh, G. (2017). Should be five-year program for teacher preparation in Vietnam (Việt nam nên đào tạo giáo viên trong 5 năm). Retrieved from https://tuoitre.vn/viet-nam-nen-dao-tao-giao-vien-trong-5-nam-20171223101808197.htm

Nhat, H. (2018). The image of Vietnam education after five years of reform (Bức tranh giáo dục Việt nam sau 5 năm đổi mới căn bản toàn diện). Retrieved from https://dantri.com.vn/giao-duc-khuyen-hoc/buc-tranh-giao-duc-viet-nam-sau-5-nam-doi-moi- 
can-ban-toan-dien-20181013111401235.htm

OECD. (2001). Competencies for the Knowledge Economy. Retrieved from http://www.oecd.org/innovation/research/1842070.pdf

OECD. (2013). Structural Policy Country Notes: Vietnam. Retrieved from https://www.oecd.org/countries/vietnam/Viet\%20Nam.pdf

Pham, T. K. A. (2016). The competency of high school teachers in the context of educational reform (Thực trạng năng lực đội ngũ giáo viên phổ thông trước yêu cầu đổi mới giáo dục phổ thông). Retrieved from http://vncsp.hnue.edu.vn/ban-tron-giao-duc/article/269.aspx

Resolution 29-NQ/TW. (2013). Fundamental and comprehensive innovation in education. Retrieved from https://thuvienphapluat.vn/van-ban/Thuong-mai/Resolution-No-29-NQ-TW-fundamental-and -comprehensive-innovation-in-education-219442.aspx

Schleicher, A. (2012). Preparing Teachers and Developing School Leaders for the 21st Century: Lessons from around the World. OECD Publishing. http://dx.doi.org/10.1787/9789264xxxxxx-en

Stronge, H. J. (2018). Qualities of Effective Teachers (3rd ed.). ASCD Publishing.

Tu, H. T., \& Hanh, T. N. (2017). Developing Curriculum \& Teacher Professional Development in Vietnam Basic Education Reform (Phát triển chương trình đào tạo, bồi dưỡng giáo viên đáp ứng yêu cầu đổi mới giáo dục phổ thông Việt Nam). Journal of Science, 33(2), 52-60

Vietnam News. (2018). Better teachers crucial to education reform. Retrieved from https://vietnamnews.vn/society/education/448914/better-teachers-crucial-to-educational-refor m.html\#iFHO4TxKgCKAIRHb.97

Yelland, N. (2006). Changing Worlds and New Curricula in the Knowledge Era. Educational Media International, 43(92), 121-131. https://doi.org/10.1080/09523980500237922

\section{Copyright Disclaimer}

Copyright for this article is retained by the author(s), with first publication rights granted to the journal.

This is an open-access article distributed under the terms and conditions of the Creative Commons Attribution license (http://creativecommons.org/licenses/by/3.0/). 